\title{
Столетию основания Высших художественно-технических мастерских посвящается
}

\author{
Е.В.Ермоленко, МАРХИ, Москва
}

В статье освещены мероприятия и события как иллюстрации структурной характеристики и фундаментальной роли выдающейся архитектурно-художественной школы ВХУТЕМАС. Педагоги Высших художественно-технических мастерских, в числе которых А. Веснин, Н. Ладовский, И. Леонидов, К. Мельников, А. Щусев, Э. Лисицкий, В. Татлин и многие другие, оказали колоссальное влияние на становление и развитие мировой архитектуры и искусства XX-XXI веков. Закономерно, что юбилейные мероприятия прошли под эгидой Комиссии Российской Федерации по делам ЮНЕСКО. В мероприятиях приняли участие высшие архитектурные школы России, зарубежные исследователи из Германии, Италии, США и других стран, Российская академия художеств, Российская академия архитектуры и строительных наук, Союз архитекторов России и Союз московских архитекторов. В Музее Москвы, Музее архитектуры им. А. Щусева и на других площадках организованы выставки, посвящённые становлению школы, организации и методике учебного процесса во ВХУТЕМАСе.

Ключевые слова: ВХУТЕМАС-100, фундаментальный вклад в архитектурно-художественную культуру XX-XXI веков, анализ событий, международная научная конференция, выставка в Музее Москвы, коллективная монография «ВХУТЕМАС в мировой культуре XX-XXI веков».

\section{On the Centennial of the Higher Art and Technical Studios}

\section{E.V.Ermolenko, MARKHI, Moscow}

The article covers a variety of events and events that took place in the framework of the centenary of the outstanding VKhUTEMAS school of architecture. Teachers of Higher art and technical workshops, including A. Vesnin, M., N. Ladovsky, I. Leonidov, K. Melnikov, A. Shchusev; E. Lisitsky, V. Tatlin and many others, had a tremendous influence on the formation and development of the entire world architecture of the $X X-X X I$ centuries. It is no accident that the anniversary events were held under the auspices of UNESCO. The events were attended by the largest architectural universities in Russia, foreign researchers from Italy, Germany, the USA and other countries, the Russian Academy of Arts, the Russian Academy of architecture and construction Sciences, the largest architectural communities - the Union of architects of Russia and the Union of Moscow architects. The Museum of Moscow, the Shchusev Museum of architecture and other venues have organized exhibitions dedicated to the formation of the school and the organization of the educational process in VKhUTEMAS.

Keywords: VKHUTEMAS-100, anniversary events, international scientific conference, exhibition in the Museum of Moscow, collective monograph MARKHI, RAH, MGHPA of Stroganov, Moscow Polytechnic Institute, Kosygin Russian state University, Surikov Moscow state technical University.

2020 год - год столетнего юбилея всемирно известной архитектурной школы ВХУТЕМАС: Высшие художественнотехнические мастерские были созданы Декретом Совнаркома от 29 ноября 1920 года.

Новаторские методики преподавания и учебные дисциплины, новое понимание пространства и приёмов его построения и восприятия, новые формы архитектуры, зарождение современного дизайна, все виды художественного творчества - такова роль школы в формировании эстетики нового мира, новой проектной культуры.

Исследованием наследия ВХУТЕМАСа занимаются многие учёные, культурологи, искусствоведы, архитекторы из самых разных стран мира (рис. 1 а, б). Явление поистине мирового масштаба, школа ВХУТЕМАС продолжает оказывать влияние на современную проектную и художественную практику, дизайн. Новый архитектурный язык формообразования и построения пространства, предложенный архитекторами и художниками школы, и сегодня является жизнеспособным и актуальным. Организация учебного процесса, методики преподавания, разработанные во ВХУТЕМАСе, живут в современной архитектурной высшей школе, в частности, пропедевтика, дисциплина «Пространство».

Учитывая важность юбилейной даты основания всемирно известной архитектурно-художественной школы, отмечая огромный вклад учителей и выпускников ВХУТЕМАСа в становление мировой культуры первой половины XX века и их влияние на последующее мировое зодчество и искусство, все мероприятия официальной программы прошли под эгидой Комиссии РФ по делам ЮНЕСКО.

В Москве в организации юбилейных мероприятий приняли участие вузы-наследники: Московский архитектурный институт (государственная академия), МГХПА им. С.Г. Строганова, Московский политехнический институт, РГУ им. А.Н. Косыгина, МГАХИ им. В.И. Сурикова. Российская академия художеств, Российская академия архитектуры и строительных наук, Союзы архитекторов России и Союз московских архитекторов, Музей Москвы, Музей архитектуры им. А.В. Щусе- 


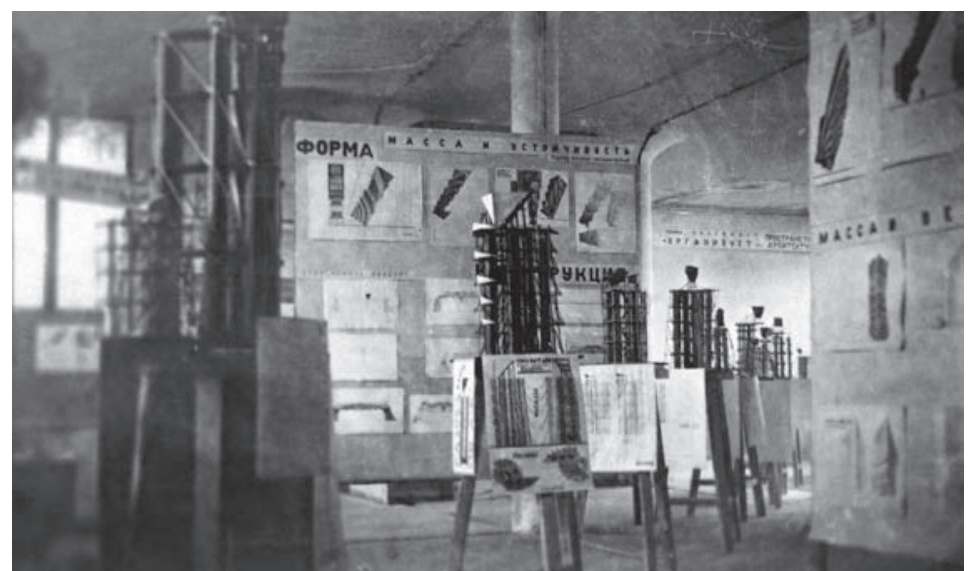

a)

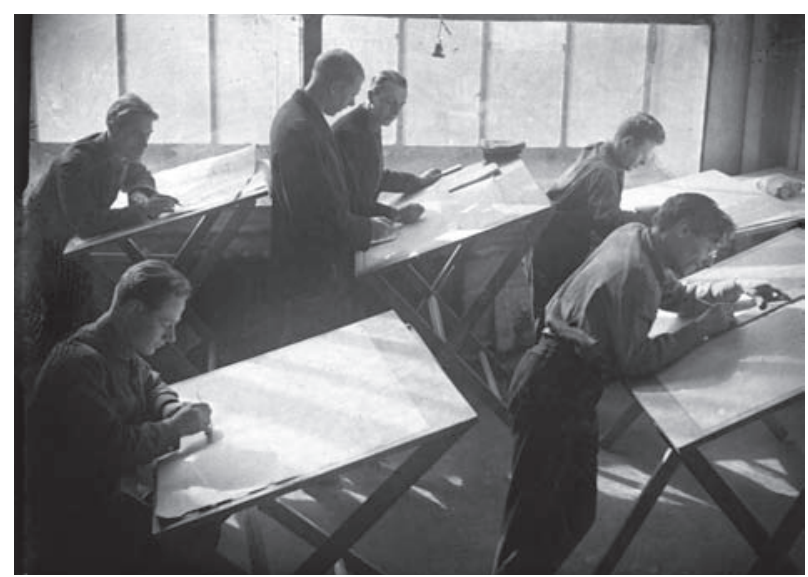

6)

PUс. 1. Учебный процесс в школе ВХУТЕМАС (фото из открытых источников сети Интернет): а) выставка учебных проектов; б) на занятиях по дисциплине «Культура материала» В. Татлина

ва, галерея «На Шаболовке» и многие другие профессиональные организации и сообщества представили своё видение значения и вклада ВХУТЕМАСа-ВХУТЕИНа в развитие культуры.

Организованы две информационные платформы: www. vhutemas.ru - создана Московским архитектурным институтом, и https://vhutemas.mosmuseum.ru/ - онлайн платформа Музея Москвы, посвящённая юбилею школы.

\section{Выставки, приуроченные к созданию школы ВХУТЕМАС}

Уникальная экспозиция «ВХУТЕМАС-100. Школа авангарда» начала работу в Музее Москвы (рис. 2). В ней представлены живописные и графические работы, архитектурные проекты и макеты, предметы промышленного дизайна, скульптура, фотографии и архивные текстовые материалы.

Экспозиция последовательно в соответствии с этапами становления раскрывает историю школы - от момента её зарождения до создания ныне известных проектов учителей и студентов учебного заведения.

История каждого факультета выделена в отдельном экспозиционном пространстве. Впервые показаны работы всех факультетов: Архитектурного, Скульптурного, Живописного, Полиграфического, Текстильного, Керамического, Деревообделочного и Металлообрабатывающего. По блокам сгруппированы работы учащихся Основного отделения по дисциплинам: «Пространство», «0бъём», «Графика» и «Цвет». Завершает экспозицию раздел, посвященный работам наследников ВХУTEMACa $^{1}$. Эта часть выставки раскрывает феномен традиций, столь важный для понимания роли ВХУТЕМАСа в рождении новой проектной культуры.

Продолжают эту концепцию развития традиций выставки в МГХПА им. С.Г. Строганова «Время ВХУТЕМАС. К 100-летию создания школы» и «ВХУТЕМАС-100»: от курсовых проектов ВХУТЕМАСа до наследия школы в современных проектах

\footnotetext{
${ }^{1}$ Кураторская экскурсия А. Н. Селивановой доступна по ссылке: https://
} www.youtube.com/watch?v=7h40Wmhu330. дизайна интерьера и мебели, транспорта и текстиля, графического дизайна и дизайна среды.

В Московском архитектурном институте при поддержке Департамента культурного наследия города Москвы от-

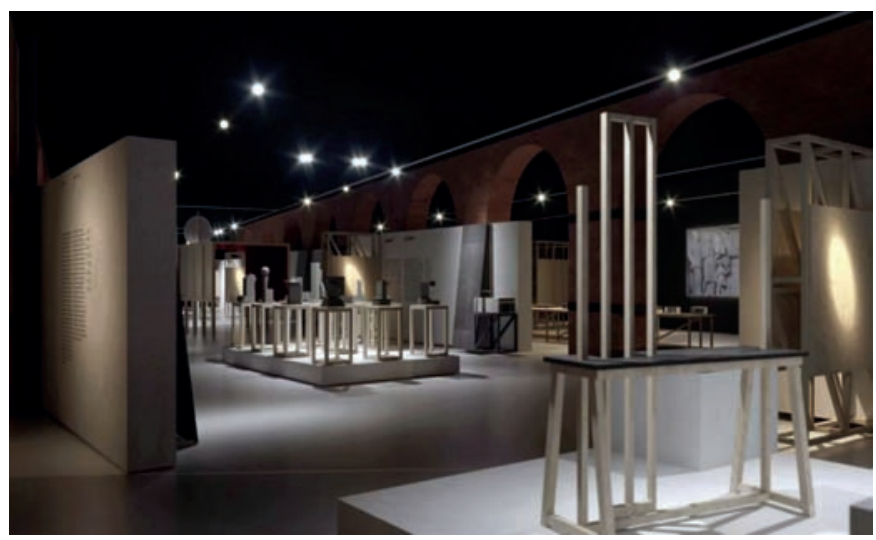

Рис. 2. Выставка «ВХУТЕМАС 100. Школа авангарда» в Музее Москвы (фото из открытых источников сети Интернет)

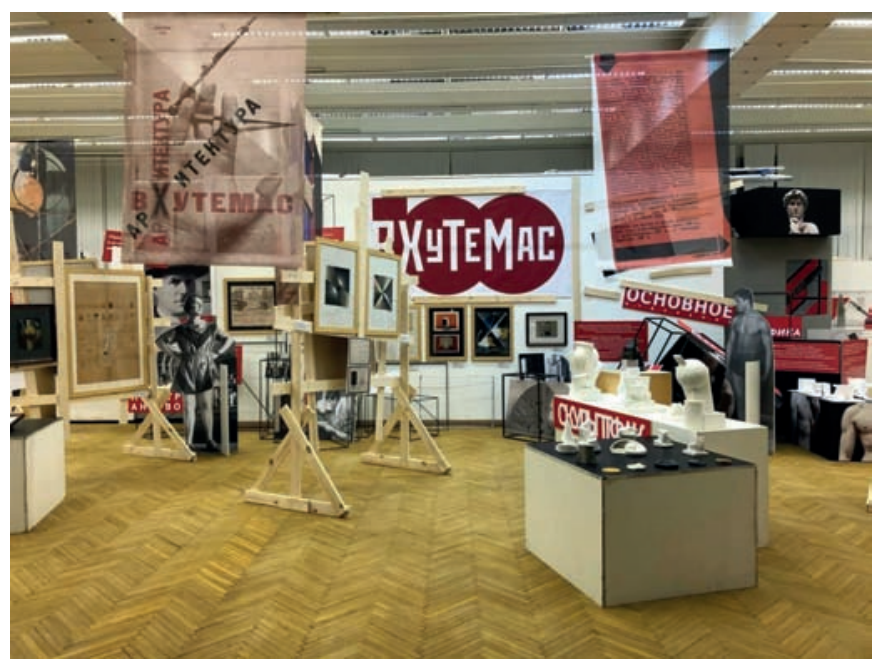

Рис. 3. Выставка «ВХУТЕМАС в МАРХИ» (фото из открытых источников сети Интернет) 
крылась выставка, приуроченная к 100-летию образования ВХУТЕМАСа (рис. 3). Выставка собрана из экспонатов Музея московской архитектурной школы при МАРХИ (кураторы - директор Музея МАРХИ профессор Л.И. Иванова-Веэн, профессора кафедры «Дизайн архитектурной среды» А.П. Ермолаев и Т.О. Шулика) ${ }^{2}$.

Оригинально содержание выставки, посвящённой работам мастеров ВХУТЕМАСа, в галерее «На Шаболовке» - «Детский ВХУТЕМАС» (кураторы выставки - А. Селиванова и К. Гусева). Впервые представлены предметы советского дизайна, разработанные специально для детей. В числе экспонатов керамика, текстиль, книги, кукольный театр и архитектурные проекты.

В Московском политехническом институте в течение 2020 года проводились различные выставочные мероприятия. С марта по июнь в рамках межвузовского проекта «Век традиций: Вхутемас. 1920 - МОСХ. 2020» в выставочном зале МOCX была представлена экспозиция, посвящённая истории и работе школы ВХУТЕМАС.

${ }^{2}$ http://marhi-archcenter.ru/VKHUTEMAS/.

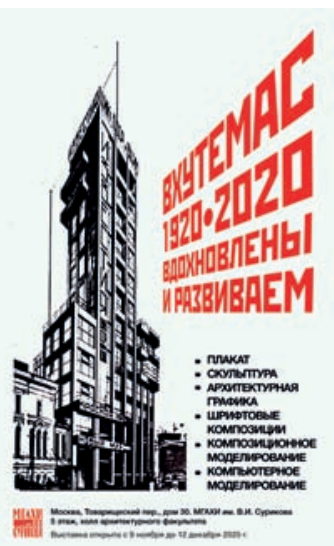

a)

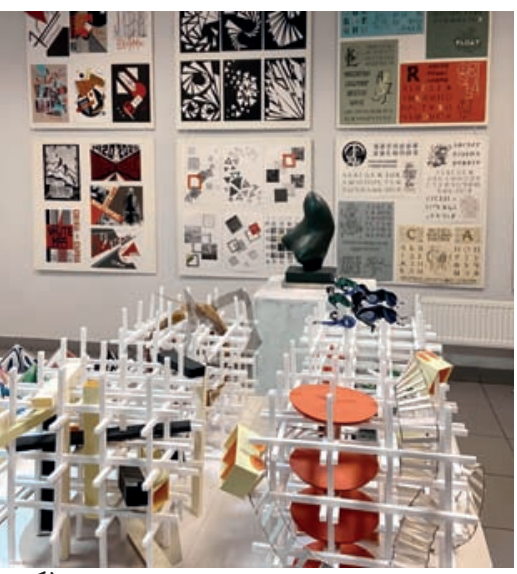
б)

РUс. 4. Выставка «ВХУТЕМАС. 1920-2020. Вдохновлены и развиваем». МГАХИ им. В.И. Сурикова (фото из открытых источников сети Интернет): а) афиша выставки; б) фрагмент экспозиции

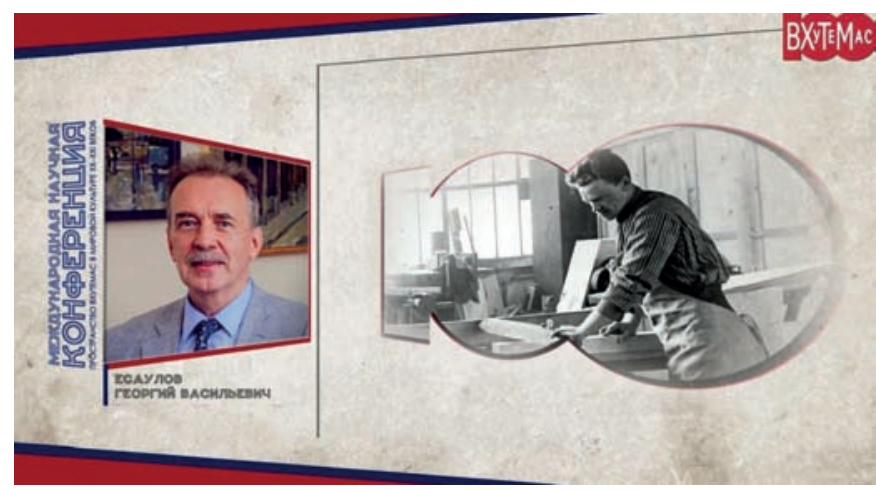

Рис. 4. Обращение от научного комитета (видео-доклад) сопредседателя научного комитета конференципи академика Г.В. Есаулова (фото из открытых источников сети Интернет)
В Музее экслибриса и миниатюрной книги представлена экспозиция под названием «Традиции и новаторство. 100-летию ВХУТЕМАСа посвящается». Выставка организована кафедрой «Рисунок и живопись» Высшей школы печати и медиаиндустрии Московского политехнического университета при поддержке Международного союза книголюбов.

Московский государственный академический художественный институт имени В.И. Сурикова при Российской академии художеств проводит выставку «ВХУТЕМАС. 1920-2020. Вдохновлены и развиваем».

На выставке представлены работы студентов факультета архитектуры по следующим направлениям: плакат, архитектурная графика, скульптура, шрифтовые композиции, композиционное моделирование, компьютерное моделирование.

До конца 2020 года проходит выставка «Эра ВХУТЕМАС» в Музее истории полиграфии, книгоиздания и МГУП имени Ивана Фёдорова Московского политехнического университета.

Международная научная конференция «Пространство ВХУТЕМАС в мировой культуре XX-XXI веков » и другие научные мероприятия

В рамках юбилейных мероприятий прошли международные научные конференции. С 9 по 15 ноября 2020 года в онлайн формате проведена конференция «Пространство ВХУТЕМАС в мировой культуре XX-XXI веков», объединившая учёных и исследователей из Москвы, Санкт-Петербурга, Самары, Саратова, Новосибирска, Томска и многих других городов России, а также участников из Великобритании, Германии, Италии, Китая, Франции, Японии (рис. 4).

Пленарные доклады участников конференции (Д.О. Швидковского, С.В. Курасова, Г. В. Есаулова, В.Р. Аронова, Кристины Лоддер, Кристиане Поста, Жан-Луи Коэна, М. Мерриджи, Федерики Даль Фалько и многих других) доступны в видео-формате на странице МАРХИ на платформе «YouTube» .

В онлайн формате с трансляцией на канале «YouTube» и сайте <www.vhutemas.ru> проведены заседания в Мо-

${ }^{3}$ https://www.youtube.com/channel/UCunV-XvyOWs7-F2I_WsGnnA

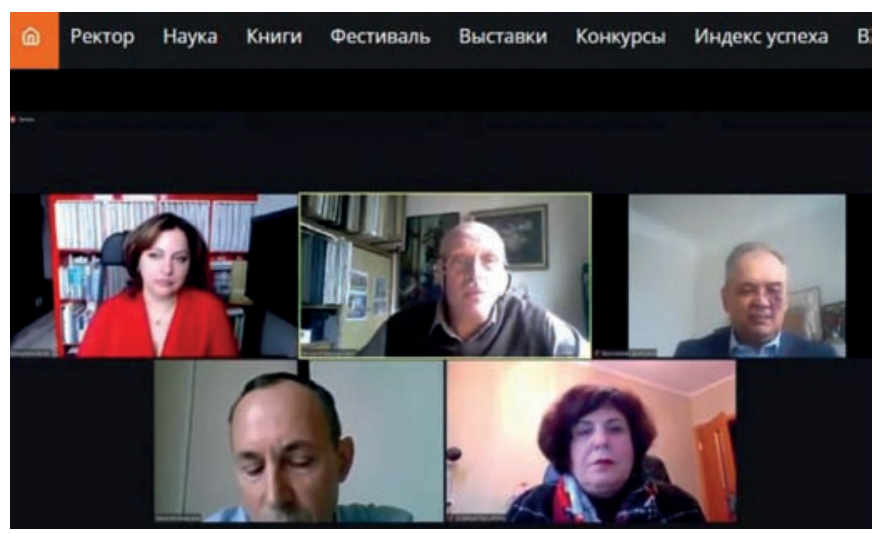

Рис. 5. Онлайн заседание секции «Архитектурно-художественное образование в Советской России 1920-х годов», МАРХИ, 10 ноября 2020 года (фото из открытых источников сети Интернет) 
сковском архитектурном институте (рис. 5), в Московской государственной художественно-промышленной академии им. С.Г. Строганова.

Состоялись онлайн-заседания XXXI Алпатовских чтений, организованные Российской академией художеств на базе Московского политехнического университета проведены заседания секции «Наследие Полиграффака ВХУТЕМАСа: традиции и современность» ${ }^{4}$.

Научная конференция «V Хан-Магомедовские чтения “Наследие ВХУТЕМАС и современность"» проведена заочно, материалы по итогам проведения готовятся к публикации в электронном научном издании НИИТИАГ «Теория и история архитектуры».

В марте 2020 года в стенах Московского государственного художественного института имени В.И. Сурикова прошла научно-практическая конференция «Московская художественная школа. К 100-летию ВХУТЕМАСа», организованная факультетом теории и истории искусств ${ }^{5}$. МГАХИ им. В.И. Сурикова сыграл значительную роль в становлении московской художественной школы XX века. Сегодняшняя методика преподавания во многом опирается на опыт педагогов ВХУТЕМАСа.

В работе конференции также приняли участие представители Государственной Третьяковской галереи, ГМИИ им. А.С. Пушкина, НИИ РАХ, Союза художников России, Союза писателей, сотрудники художественных галерей, независимые исследователи.

В стенах института педагогами и учащимися факультета теории и истории искусств под руководством доктора искусствоведения А.К. Флорковской ведётся планомерная работа по сбору и изучению исторических и методических материалов, связанных с факультетами живописи, графики и скульптуры.

\section{Новые книги}

По материалам Международной научной конференции «Пространство ВХУТЕМАС в мировой культуре XX-XXI веков» была выпущена одноимённая монография (рис. 6). В издании представлены малоизвестные страницы из истории школы, анализируется становление нового архитектурно-художественного образования, показано влияние ВХУТЕМАСа на архитектуру и искусство XXI века.

Книга состоит из шести разделов.

В первом разделе опубликованы пленарные доклады Д.О. Швидковского, Г.В. Есаулова, В.Р. Аронова, А.Н. Лаврентьева, Н. Перлофф и других учёных, рассказывающие о роли школы, о том, как воспринимается наследие ВХУТЕМАСа сегодня, о взаимосвязи двух великих архитектурно-художественных школ - ВХУТЕМАСа и БАУХАУЗа, о современной

\footnotetext{
${ }^{4}$ Информация о конференции, а также видео-запись трансляции доступны на информационных каналах МАРХИ, РАХ, МГХПА им. С.Г. Строганова.

${ }^{5}$ Информация о конференции доступна по ссылке: http://surikov-vuz. com/events/konferencii/actual/konf_k_stoletiyu_vhutemasa_2020/.
}

архитектуре, становление которой во многом произошло под влиянием идей и концептов, которые в 20-е годы прошедшего столетия предлагались педагогами-новаторами.

Второй раздел посвящён истокам и истории создания школы. В статьях раздела представлены результаты исследований процесса создания мастерских, их влияние на региональные школы, особенности преподавания на Графическом, Художественном, Архитектурном факультетах.

Третий раздел «Новое художественное и проектное мышление: пространство, объём, графика, цвет» включает научные работы о методиках развития пространственного мышления, новых приёмах создания архитектурных форм, построения композиционных решений, об искусстве фотографии, , особенностях обучения по новым дисциплинам.

В четвёртом разделе книги «0т Архфака к архитектуре XXI века» показано, как наследие ВХУТЕМАСа участвует в процессе формирования современной архитектуры, дизайна, современной художественной среды. Очевидно, что наследие ВХУТЕМАСа не только не исчерпано, но продолжает активно развиваться и интерпретироваться в самых разных вариантах в современном мире.

Пятый раздел включает материалы, объединённые темой развития авангардных школ XX века, их роли, влияния на архитектурно-художественное творчество XXI века.

В завершающем шестом разделе книги, собраны основные архивные материалы, даны хронология ВХУТЕМАСа, постановление Совета народных комиссаров о Московских высших государственных художественно-технических мастерских, а также список избранных изданий и публикаций о ВХУТЕМАСе.

Ответственные редакторы издания: Г.В. Есаулов, А.Н. Лаврентьев.

Составители и научные редакторы: Е.Ю. Баснина, Е.В. Ермоленко, Л.И. Иванова-Вэен, А.Н. Лаврентьев, А.В. Сазиков.

К столетию мастерских были выпущены и другие книги по тематике юбилея.

Так, в двухтомнике «ВХУТЕМАС-ВХУТЕИН. Полиграфический факультет. 1920-1930» представлен обширный материал о преподавателях и студентах ВХУТЕМАСа с подробной биографией художников, учившихся на Полиграфическом

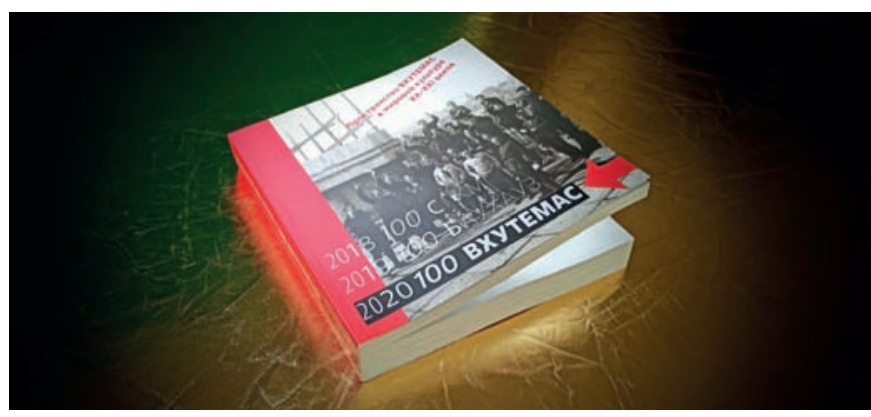

PUс. 6. Пространство ВХУТЕМАС в мировой культуре ХХ-ХХІ веков: коллективная научная монография (М. : МАРХИ, МГПА им. С.Г. Строганова, РАХ, Московский политехнический универсuтem, 2020. - 612 c.) 
факультете. Огромную ценность представляет каталог работ выпускников, многие из которых публикуются впервые (рис. 7).

Первый том включает в себя подробные биографии преподавателей Полиграффака: В.А. Фаворского, П.А. Флоренского, Л.А. Бруни, С.В. Герасимова, Н.Н. Куприянова, П.И. Львова, П.В. Мируча, Д.С. Моора, И.Н. Павлова и других, а также каталог студенческих работ и коллективные работы выпускников факультета (1927-1954). Дана систематизированная информация о художниках, учившихся на Полиграфическом факультете, обширный фото-материал, охватывающий учебный процесс, персоналии преподавателей и студентов. Несомненную ценность имеют письма и архивные материалы.

Во втором томе представлены биографии 135 художников, учившихся на Полиграфическом факультете. В издании более тысячи иллюстраций.

Редактор И.Д. Шаховской, автор-составитель Л И. Чертков, дизайн Н.Г. Ордынского ${ }^{6}$.

${ }^{6}$ Информация с сайта https://boslen.ru/vkhutyemas--vkhutyeinpoligraficheskiy-fakultet-1920-1930-v-2-t/.

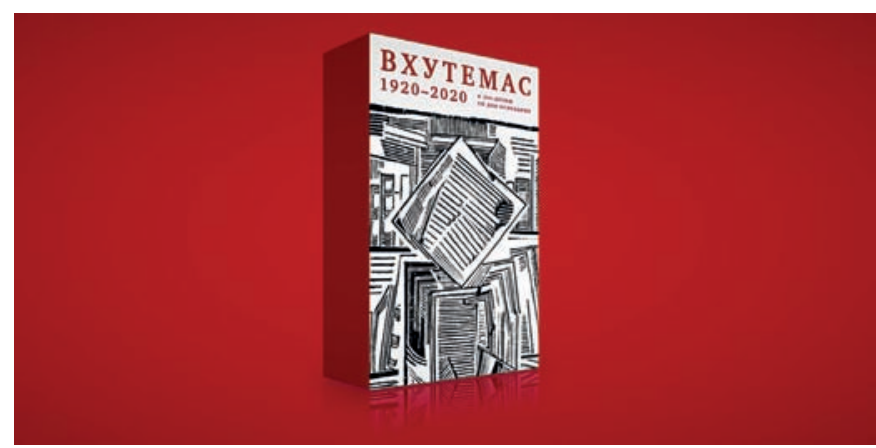

РИс. 7. ВХУТЕМАС-ВХУТЕИН. Полиграфический факультет. 1920-1930 : В 2 m. / авт.-сост. Л.И. Черток (М. : Бослен, 2020. -1360 c.)

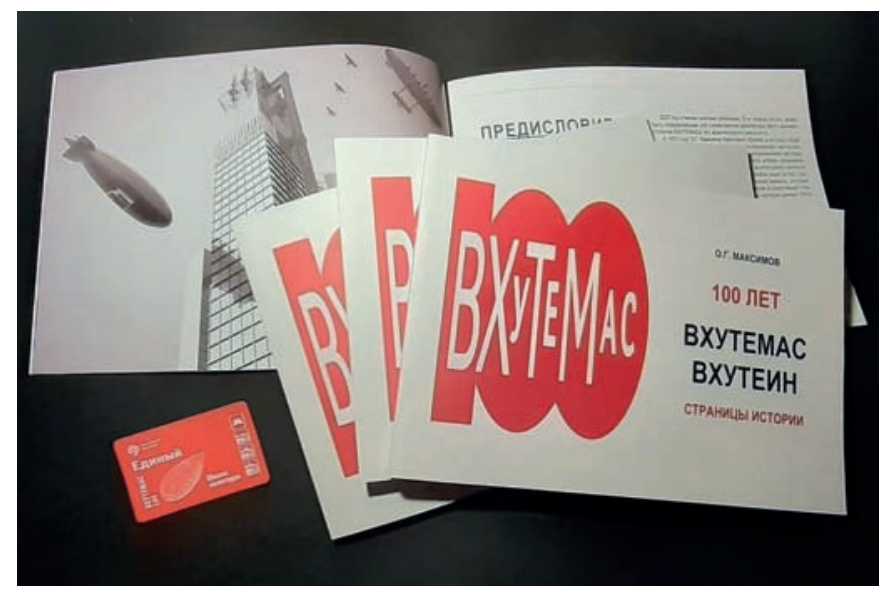

РИс. 8. Максимов О.Г. 100 лет. ВХУТЕМАС-ВХУТЕИН. Страницы истории (М. : МАРХИ, 2020. - 96 с.). Фото О.Г. Максимова
Вышло в свет монографическое учебное издание «ВХУТЕМАС-ВХУТЕИН. Страницы истории 1920-1930», автор - О.Г. Максимов, профессор МАРХИ, архитектор (рис. 8). В основу издания легли публикации работ ВХУТЕМАСа 1927 года, монографии мастеров архитектуры того времени, а также графические работы автора, представленные на международных фестивалях «30ДЧЕСТВ0». Архитектурный факультет ВХУТЕМАСа представлен в издании по трём разделам: педагоги, методика преподавания, ученики.

При участии Московского политехнического университета к юбилею школы ВХУТЕМАС выпущены в свет две книги: «Живопись. Графика. 100-летию Московского ВХУТЕМАСа посвящается» представляет собой коллективную научную монографию преподавателей-художников кафедры «Рисунок и живопись» Института графики и искусства книги имени В.А. Фаворского Высшей школы печати и медиаиндустрии Московского политехнического университета.

В книге дана краткая история становления и развития школы - от полиграфического факультета до Института графики и искусства книги имени В.А. Фаворского Московского Политеха, изложена методология преподавания; особое внимание уделено основателям и последователям школы В.А. Фаворскому, А.В. Васнецову, К.Н. Истомину, Д.Д. Жилинскому и многим другим.

В книге «Полиграффак ВХУТЕМАСа. Очерки разных лет. 100-летию Московского ВХУТЕМАСа посвящается» собраны очерки истории Полиграфического факультета ВХУТЕМАСа-ВХУТЕИНа. Автор издания - Н.Л. Адаскина, кандидат искусствоведения, научный сотрудник Государственной Третьяковской галереи, исследователь истории полиграфического факультета Московского ВХУТЕМАСа

Издание включает семь глав, каждая из которых посвящена отдельной странице из истории школы.

\section{Конкурсы и иные мероприятия в рамках юбилея школы ВХУТЕМАС}

На протяжении 2020 года в рамках юбилея проводились многочисленные конкурсы, форумы, научные дискуссии и круглые столы, записывались онлайн лекции.

На Московскую международную биеннале графического дизайна «Золотая пчела 14» было представлено более 90 плакатов, посвящённых юбилеям ВХУТЕМАСа и БАУХАУСа, столетие которого отмечалось в 2019 году. Куратором конкурса выступил проректор по научной работе МГХПА им. С.Г. Строганова А.Н. Лаврентьев.

Впервые в отечественной практике архитектурного и художественного образования был проведён Всероссийский конкурс инновационных методических разработок в области архитектурного, дизайнерского и художественного образования, декоративного искусства и реставрации.

${ }^{7}$ Презентация книг доступна в записи на канале Музея Москвы, платформа «YouTube»: https://www.youtube.com/watch?v=JKleQeCkYHg. 
Конкурс, посвящённый 100-летию создания ВХУТЕМАСа, организовали Федеральные учебно-методические объединения при Минобрнауки России «Архитектура» (председатель Г.В. Есаулов) и «Изобразительное и прикладные виды искусства (председатель В.Ф. Зива). Взаимодействие Ум0 демонстрировало синтез факультетов и специальностей ВХУТЕМАСа.

Исключительное место конкурса в череде юбилейных мероприятий объясняется важностью методологии и методики преподавания в развитии современной архитектуры, дизайна и изобразительных и прикладных видов искусств. Инновации ВХУТЕМАСа, став отправной точкой развития новой системы образования, определили модели и алгоритмы разработки научно-методических инноваций. С одной стороны, конкурс дал возможность переосмыслить роль методик ВХУТЕМАСа как синтетических средств создания новых форм, новых образов и становления творцов новой архитектурно-художественной культуры. С другой - конкурс может быть рассмотрен как возможность демонстрации достижений в области инноваций архитектурно-художественного образования в современной России.

На конкурсе было представлено около ста разработок. Согласно условиям, это программы дисциплин и курсов по самым различным номинациям. В области архитектуры: «проектные дисциплины», «академические дисциплины», «инженерные и вспомогательные дисциплины». По направлениям подготовки «Изобразительные и прикладные виды искусств: «учебные программы по проектированию (бакалавриат, магистратура), специалитет»; «методика, методология и проектно-исследовательские дисциплины»; «академические дисциплины»; «вспомогательные дисциплины».

Жюри конкурса под сопредседательством Г.В. Есаулова, В.Ф. Зива, А.Н. Лаврентьева подвело итоги конкурса. Победители конкурса удостоены звания лауреата и награждены дипломами 1, 2, 3 степени и специальными дипломами жюри. Ими стали педагоги из Москвы, Санкт-Петербурга, Екатеринбурга, Ижевска, Набержных Челнов, Нижнего Новгорода, Новосибирска, Ростова-на-Дону, Симферополя, Тюмени. Очевидно, что опыт разработок победителей будет востребован в академической среде творческих школ современной России и в развитии традиций инноваций, заложенных во ВХУТЕМАСе.

Международный конкурс на художественную концепцию «Музей ВХУТЕМАС» стал интересным опытом для студентов различных архитектурных вузов (рис. 9). Победители конкурса были объявлены на XXVIII Международном архитектурном фестивале «Зодчество 2020».

Музей Москвы совместно с Институтом «Стрелка» провёл онлайн фестиваль «ВХУТЕМАС-100», участие в котором приняли российские и зарубежные искусствоведы, архитекторы, дизайнеры.

В Институте графики и искусства книги имени В.А. Фаворского проведён круглый стол «Век традиций. ВХУТЕМАС 1920 - MOCX 2020».

\section{***}

Предварительный анализ результатов комплекса юбилейных мероприятий позволяет сделать несколько выводов. Несмотря на все сложности и ограничительные меры, с которыми пришлось столкнуться в 2020 году из-за пандемии, юбилей Высших художественно-технических мастерских был отмечен чрезвычайно широко. Освещение в СМИ и профессиональных изданиях, полемика и дискуссии в интернете, специальные телепрограммы, посвящённые юбилейным мероприятиям, онлайн конференции, фестивали, конкурсы, круглые столы, а также открытие значимых, уникальных по составу экспонатов выставок, выпуск новых книг, монографий - всё это демонстрирует интерес к истории великой школы, к осмыслению её влияния и роли уникального культурного явления - ВХУТЕМАСа.

В организации выставок предпочтение кураторов отдаётся систематизации экспонатов, осмотр которых позволяет глубже понять и переосмыслить, казалось бы, известные факты. Предыстория формирования мастерских, зарождение авангардных идей, а также их влияние на дальнейшее развитие архитектуры, дизайна, искусства - линия, объединяющая несколько выставок. Демонстрация малоизвестных фотографии учебного процесса, редких работ учеников, ставших первыми образцами нового художественного мышления, писем и архивных материалов - всё это позволяет по-новому взглянуть на наследие школы, остро прочувствовать новаторские идеи и программы.

Большое внимание уделено демонстрации деятельности факультетов ВХУТЕМАСа. Каждый факультет сегодня рассматривается как отдельное масштабное явление со своей уникальной культурой преподавания, методикой работы, общения с учениками. Являясь частью общей системы обучения в школе, каждый факультет тем не менее имел свои индивидуальные черты, напрямую связанные с именами педагогов и их профессиональными предпочтениями. Сегодня выявление этих индивидуальных особенностей становится приоритетным в формировании экспозиции.

Важную роль играют выставки, проводимые вузами - наследниками Высших художественно-технических мастерских. Здесь позиция кураторов направлена на выявление преемственности и последовательное продолжение традиций ВХУТЕМАСа. Зачастую экспрессивные, эпатажные формы

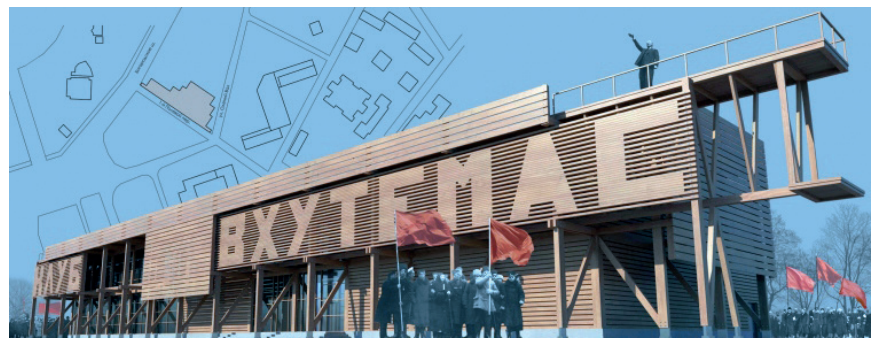

РИс. 9. Проект клуба-музея ВХУТЕМАС. Автор К.Д. Шаповалов (фото из открытых источников сети Интернет) 
предъявления экспонатов призваны «связать» современность с динамикой, напряжённостью, яркостью революционных идеи ВХУТЕМАСа.

В рамках научных дискуссий и конференций отчётливо прослеживается поиск пересечений, возможных влияний двух школ - ВХУТЕМАСа и БАУХАУСа, а также современное восприятие новаторских педагогических программ, практики, переосмысление деятельности школ в контексте социальных изменений в обществе. По-прежнему внимание исследователями уделяется персоналиям архитекторов, художников, скульпторов, графиков, мастерство которых, как некая духовная энергия, бесконечно меняясь, меняет жизнь вокруг себя. Отмечается, что при всеобщем признании величия наследия ВХУТЕМАСа в отечественной практике редко происходит следование именно архитектурным принципам, сформулированным педагогами школ. Изучение пропедевтики, созданной во ВХУТЕМАСе, позволяет по-новому взглянуть и на современные методы преподавания и обучения студентов в архитектурных и художественных школах. Преемственность наследия, влияние на региональные школы и, шире, на мировую архитектурно-художественную практику XX-XXI веков, рассматривается сегодня сквозь призму прошедшего времени.

Важно отметить издание новых книг и монографий, глубоких, системных исследований наследия ВХУТЕМАСа. Многообразие выпущенных к юбилею изданий свидетельствует о сохранении интереса к истории школы, даёт основание предположить, что в будущем сохранится традиция обновления художественного и архитектурного образования, заложенная в образовательных программах более века назад, принципы фундаментальности и новаторских поисков по-прежнему будут оставаться актуальными и востребованными.

Чрезвычайно значимыми можно считать результаты конкурсов. Студенческий конкурс на музей ВХУТЕМАСа демонстрирует ряд важнейших черт времени. Два первых места в конкурсе заняли студенты Московского архитектурного института - прямого наследника легендарной школы ВХУТЕМАСа. Проект Е. Кестер, И. Заикина и Ю. Гришиной, удостоенный первой премии, демонстрирует возрождение функции мастерских, антитезу статичному музею. Динамичный, меняющийся в соответствии с творческим процессом комплекс, по замыслу авторов, должен быть современной площадкой для любых самых смелых исследовательских, образовательных, творческих процессов. Иными словами, структура обучения в Высших художественно-технических мастерских легла в основу формирования конкурсного проекта. Современная интерпретация, «вчувствование» студентами назначения школы демонстрирует преемственность поколений, несомненно обусловленную актуальностью и жизнеспособностью учебных программ и дисциплин ВХУТЕМАСа, на которых взращено не одно поколение архитекторов.
Можно с уверенностью утверждать, что современные архитектурные и художественные школы несомненно помнят и ценят наследие ВХУТЕМАСа. Дальнейшее осмысление учебных программ, оцифровка архивных данных, введение в научное знание новых материалов продолжится. Изучение истинно масштабного культурного явления, каким является школа ВХУТЕМАС, не ограничено временными рамками.

\section{Литература}

1. Александров, Г.А. Иван Леонидов / Г.А. Александров, С.0. Хан-Магомедов. - М. : Стройздат, 1971. - 127 с.

2. Баухаус в контексте мирового зодчества. К 100-летию Баухаус в рамках программы ЮНЕСКО : Коллективная научная монография / Материалы Международной научно-практической конференции XXX Алпатовские чтения. - М. : Студия R.PR.studio, 2020. - 322 c.

3. Великая утопия: Русский и советский авангард 1915-1932 г. : Каталог / Министерство культуры Российской Федерации, Государственная Третьяковская галерея, Государственный Русский музей, Российский художественнопроизводственный комбинат. - М. : Галарт, Берн : Бентелли, 1993. - 832 c.

4. Иван Леонидов. Начало XX-XXI века. Материалы. Воспоминания. Исследования / Под общ.ред. Н.Л. Павлова. - М., 2002. - 213 с.

5. Иконников, А.В. Функция, форма и образ в архитектуре / А.В. Иконников. - М. : Строиздат, 1986. - 288 с.

6. Кандинский, B. 0 духовном в искусстве. Ступени. Текст художника. Точка и линия на плоскости / В. Кандинский; перевод с немец. Н.И. Дружковой. - М. : АСТ, 2018. - 384 с.

7. Архитектура авангарда. Москва. Вторая половина 1920-х - первая половина 1930-х годов / Е. Овсянникова, Н. Васильев, М. Евстратова, 0. Панин. - М., 2011. - 480 с.

8. От ВХУТЕМАСа к МАРХИ. 1920-1936. Архитектурные проекты из собрания музея МАРХИ / руковод.проекта Л. И. Иванова-Вэен, отв.ред. А. П. Кудрявцев, науч.рук. Н. 0. Душкина, научн.консульт. С. 0. Хан-Магомедов и др. - М. : А.-Фонд, 2005. - 232 с.

9. Пространство ВХУТЕМАС в мировой культуре XX-XXI веков : коллективная научная монография. - М. : МАРХИ, МГПА им. С.Г. Строганова, РАХ, Московский политехнический университет, 2020. - 612 с.

10. Пространство ВХУТЕМАС: Наследие. Традиции. Новации / Материалы Всероссийской научной конференции, 17-19 ноября 2010 г. / РААСН, МАРХИ, МГХПА им. С.Г. Строганова и др; руководитель проекта А.П. Кудрявцев. - М. : МАРХИ, МГХПА им. С. Г. Строганова, 2010. - 240 с.

11. Родченко А.М. Степанова В.Ф. : Альбом / Автор вступ. слова, состав. А.Н. Лаврентьев. - М. : Книга, 1989. - 159 с.

12. СГХМ. Из столицы в регионы. 1918-1920-е гг. / Материалы Всероссийской конференции 24-26 декабря 2018 г. МАРХИ, МГХПА им. С. Г. Строганова. - М. : МАРХИ, 2018. - 143 c. 
13. Селиванова, А.Н. Постконструктивизм. Власть и архитектура в 1930-е годы в СССР: монография / А.Н. Селиванова. - М. : БуксМарт, 2019. -319 с.

14. Сидорина, Е.В. Русский конструктивизм: истоки, идеи, практика / Е.В. Сидорина. - М., 1995. - 552 с.

15. Хан-Магомедов, С.О. Архитектура советского авангарда : В 2 кн. Кн. 1. Проблемы формообразования. Мастера и течения / С. О. Хан-Магомедов. - М. : Строиздат, 1996. - 709 с.

16. Хан-Магомедов, С.О. Конструктивизм - концепция формообразования / С.0. Хан-Магомедов. - М. : Строиздат, 2003. - 575 c.

17. Хан-Магомедов, С.0. 100 шедевров советского архитектурного авангарда / С.0. Хан-Магомедов. - М. : Едиториал уРCC, 2005. - 456 c.

18. Хан-Магомедов, С.О. Супрематизм и архитектура (проблемы формообразования) / С.О. Хан-Магомедов. - М. : Архитектура-С, 2007. - 519 с.

19. Хан-Магомедов, С.О. Казимир Малевич. - М. : Фонд «Русский авангард», 2009. - 272 с.

20. Хан-Магомедов, С.О. Николай Ладовский / С.0. ХанМагомедов. - М. : С.Э.Гордеев, 2011. - 368 с.

21. Хан-Магомедов, С.О. Сто шедевров советского архитектурного авангарда: билингва /С.О. Хан-Магомедов. - М. : Едиториал УРСС, 2005. - 456 с.

22. Энциклопедия русского авангарда: Изобразительное искусство. Архитектура : В 3 т. / Авт.-сост. В.И. Ракитин, А.Д. Сарабьянов; науч.ред. А.Д. Сарабьянов. - М. : RA, Global expert \& Service Team, 2013. - 2068 c.

\section{References}

1. Aleksandrov G.A., Khan-Magomedov S.0. Ivan Leonidov. Moscow, Stroizdat Publ., 1971, 127 p.

2. Baukhaus $v$ kontekste mirovogo zodchestva. K 100 -letiyu Baukhaus v ramkakh programmy YuNESKO. Kollektivnaya nauchnaya monografiya. Materialy Mezhdunarodnoi nauchno-prakticheskoi konferentsii XXX Alpatovskie chteniya [Bauhaus in the context of world architecture. To the 100th anniversary of the Bauhaus in the framework of the UNESCO program. Collective scientific monograph. Materials of the International scientificpractical conference XXX-e Alpatov readings]. Moscow, Studiya R.PR.studio, 2020, 322 p.

3. Velikaya utopiya: Russkii i sovetskii avangard 1915-1932 g. Katalog [The Great Utopia: Russian and Soviet Avant-garde 1915-1932. Catalog]. Moscow, Galart Publ, Bern, Bentelli Publ., 1993, 832 p.

4. Pavlov N.L. (ed.). Ivan Leonidov. Nachalo XX- XXI veka. Materialy. Vospominaniya. Issledovaniya [Ivan Leonidov. The beginning of the XX-XXI century. Materials. Memories. Research]. Moscow, 2002, $213 \mathrm{p}$.

5. Ikonnikov A.V. Funktsiya, forma i obraz v arkhitekture [Function, form and image in architecture]. Moscow, Stroizdat Publ., 1986, 288 p.
6. Kandinskii V. 0 dukhovnom v iskusstve. Stupeni. Tekst khudozhnika. Tochka i liniya na ploskosti [On the Spiritual in Art. Steps. Artist's text. Point and line on a plane]. Translated from German N.I. Druzhkova. Moscow, AST Publ., 2018, 384 p.

7. Ovsyannikova E., Vasil'ev N., Evstratova M., Panin 0. Arkhitektura avangarda. Moskva. Vtoraya polovina 1920-kh pervaya polovina 1930-kh godov [Avant-garde architecture. Moscow. The second half of the 1920s - the first half of the 1930s.]. Moscow, 2011, 480 p.

8. Ot VKhUTEMASa k MARKhI. 1920-1936. Arkhitekturnye proekty iz sobraniya muzeya MARKhI [From VKHUTEMAS to MARCHI. 1920-1936. Architectural projects from the collection of the Moscow Architectural Institute]. A.P. Kudryavtsev (ed.). Moscow, A.-Fond Publ., 2005, 232 p.

9. Prostranstvo VKhUTEMAS $v$ mirovoi kul'ture $X X-X X I$ vekov [VKHUTEMAS space in the world culture of the XX-XXI centuries], a collective scientific monograph. Moscow, MARKHI, MGPA named after S.G. Stroganov, Russian Academy of Arts, Moscow Polytechnic University Publ., 2020, 612 p.

10. Prostranstvo VKhUTEMAS: Nasledie. Traditsii. Novatsii. Maetarialy Vserossiiskoi nauchnoi konferentsii, 17-19 noyabrya 2010 g. [Space VKHUTEMAS: Heritage. Traditions. Innovations: Maetarials of the All-Russian Scientific Conference, November 17-19, 2010]. Moscow, MARKhI, MGKhPA im. S. G. Stroganova Publ., 2010, 240 p.

11. Rodchenko A.M. Stepanova V.F. : Al'bom [Rodchenko A.M. Stepanova V.F. : Album]. A.N. Lavrent'ev (author entry. words, composition. A.N. Lavrentyev). Moscow, Kniga Publ., 1989, 159 s.

12. SGKhM. Iz stolitsy v regiony. 1918-1920-e gg. Materialy Vserossiiskoi konferentsii 24-26 dekabrya 2018g. MARKhI, MGKhPA im. S.G. Stroganova [SGHM. From the capital to the regions. 1918-1920s Materials of the All-Russian conference December 24-26, 2018 MARCHI, MGHPA named S.G. Stroganov]. - M.: MARKhI, 2018. - $143 \mathrm{~s}$.

13. Selivanova A.N. Postkonstruktivizm. Vlast' i arkhitektura $\checkmark$ 1930-e gody $\vee$ SSSR [Postconstructivism. Power and architecture in the 1930s in the USSR]. Moscow, BuksMart Publ., 2019, 319 p.

14. Sidorina E.V. Russkii konstruktivizm: istoki, idei, praktika [Russian constructivism: origins, ideas, practice]. Moscow, 1995, $552 \mathrm{p}$.

15. Khan-Magomedov S.0. Arkhitektura sovetskogo avangarda [Russian constructivism: origins, ideas, practice]. In 2 books. Book 1. Problemy formoobrazovaniya. Mastera i techeniya [Problems of shaping. Masters and trends]. Moscow, Stroizdat Publ., 1996, 709 p.

16. Khan-Magomedov S.0. Konstruktivizm - kontseptsiya formoobrazovaniya [Constructivism - the concept of shaping]. Moscow, Stroizdat, 2003, 575 p.

17. Khan-Magomedov S.0. 100 shedevrov sovetskogo arkhitekturnogo avangarda [100 masterpieces of the Soviet architectural avant-garde]. Moscow, Editorial URSS Publ., 2005, 456 p. 
18. Khan-Magomedov S.0. Suprematizm i arkhitektura (problemy formoobrazovaniya) [Suprematism and architecture (problems of shaping)]. Moscow, Arkhitektura-S Publ., 2007, 519 p.

19. Khan-Magomedov S.0. Kazimir Malevich. Moscow, Fond "Russkii avangard", 2009, 272 p.

20. Khan-Magomedov, S.0. Nikolai Ladovskii. Moscow, S.E. Gordeev Publ., 2011, 368 p.

21. Khan-Magomedov, S.0. Sto shedevrov sovetskogo arkhitekturnogo avangarda: bilingva [One hundred masterpieces of the Soviet architectural avant-garde: bilingual]. Moscow, Editorial URSS, 2005, 456 p.

22. Rakitin V.I. (auth.-comp.)., Sarab'yanov A.D. (scientific ed.) Entsiklopediya russkogo avangarda: Izobrazitel'noe iskusstvo. Arkhitektura [Encyclopedia of the Russian Avantgarde: Fine Arts. Architecture]. In 3 volumes. Moscow, RA, Global expert \& Service Team Publ., 2013, 2068 p.

Ермоленко Елена Валентиновна (Москва). Кандидат архитектуры. Доцент кафедры «Советская и современная зарубежная архитектура» ФГБОУ В0 «Московский архитектурный институт (государственная академия) (107031, Москва, улица Рождественка, дом 11/4. МАРХИ). Ученый секретарь Научного комитета Международной научной конференции, посвященной 100-летию ВХУТЕМАСа. Эл.почта: markhi_ermolenko@mail.ru

Ermolenko Elena V. Candidate of Architecture, Associate Professor of the Department of Soviet and modern foreign architecture of the Moscow Institute of Architecture (11/4 Rozhdestvenka st, Moscow, 107031. MARKHI), Member of the UMA, Member of the Russian branch of the international organization DOCOMOM0, Scientific Secretary of the Scientific Committee of the International Scientific Conference dedicated to the 100th anniversary of VKHUTEMAS. E-mail: markhi_ermolenko@mail.ru 